\title{
Den flyktige friskheten
}

\author{
Kjære lege, du som kan - ta til orde \\ for å snakke om hva det vil si \\ å være frisk. Det er ikke enkelt, \\ men det må gjøres.
}

Som legmann ville jeg i utgangspunktet mene at det å være frisk, sånn rent subjektivt, vil si ikke å kjenne symptomer på at det er noe som feiler meg. Ingen ting plager meg - ergo er jeg frisk. Et «problem» og en utfordring med friskheten er at den unndrar seg oppmerksomhet. Den er på sett og vis en «negativ» tilstand - pussig nok. Et fravær av symptomer på sin motsats. Den trenger seg ikke på, og den er flyktig. Jeg vet at hvis noen andre, for eksempel en lege, sier at jeg er syk, så er jeg nok det, selv om jeg føler meg helt frisk.

Opplevelsen av å føle seg frisk kan skaffes til veie ved hjelp av mye rart medikamenter, kraftige inntrykk, forbudte stoffer, folk og dyr - så den subjektive opplevelsen er nok ikke helt til å stole på. Sånn rent objektivt. Her kommer det forebyggende helsevesenet inn. Det vil gjerne finne ut om plager som kommer, men som ikke har manifestert seg enda. Det er en flott og viktig ting, men forebyggingen har en side eller to som ikke er så aldeles flotte.

Jeg har nettopp rundet 60 og ser eldre folk rundt meg overalt, i alle fasonger og hastigheter. Kanskje skulle jeg tatt en tur til fastlegen og fått sjekket kolesterolet. Det har alltid vært for høyt, og mannfolk i min slekt dør som fluer i 60-årene. Kanskje skulle jeg også sjekket armen som er blitt litt vond og slarkete. Men jeg lar det være - for jeg har min egen stedfortredende «fastlege» - en hund som gjør at jeg starter hver dag med en god latter og slutter hver dag med å være sliten etter turen i marka. Det er det voldsomt mye helse i. Det er blitt min «medisin». Jeg føler meg altså frisk, så da drister jeg meg til å si at jeg er det - jeg vil ikke at noen skal «avsløre» at jeg ikke er det.

For hva skal vi gjøre - du og jeg og helsevesenet og samfunnet - for at den $\varnothing$ øende andelen av befolkningen som blir eldre og eldre, skal ha det bra? Bra nok.

Svaret er ikke bare at vi skal overvåke hverandre på mer og mer utspekulerte måter. Svaret er også at vi i lag og på like fot tenker sammen og snakker sammen om hva det vil si å være frisk - ikke bare hva det vil si å være syk. Om hva vi skal bruke helsevesenet til å reparere, og til hvilken pris. Det er ikke slik at jeg som privatperson kan hyle som en markskrikersk unge på alt som er å få av behandling. Eller er det det? For hvis det er slik, da får vi et mer og mer formyndersk helsevesen som tar flere og flere beslutninger for oss, og det vil vi vel ikke - ikke vi som er så gamle.

Jo tidligere vi kan oppdage tilstander i kropp og sinn, tilstander som etter hvert har potensial til å utvikle seg slik at de gjør oss syke, desto tidligere gjør de oss «syke». Vi utvider så å si rammene for hva det vil si å være syk. På det friske livets bekostning. Det er ikke bare bra. Jeg føler meg sikker på at dette diskuteres jevnt og trutt i det medisinske miljøet, men kanskje ikke heftig nok.

Snart, ganske snart vil vi komme til å utstyre hverandre med permanente overvåkingsremedier som registrerer allehånde verdier for ditt og datt, styrt av en app som kanskje er utviklet av en oppfinnsom datanerd fra Vancouver. Og så kommer vi rennende til fastlegen fordi det lyste rødt på mobilen om morgenen. Det vil vi vel ikke - eller vil vi det? Og hvem definerer «verdiene»?

Kjære venner - ta til orde for å snakke om hva det vil si å være frisk. Her ute hos oss. Det er ikke enkelt, men det må gjøres. Og i den debatten er vi alle kvalifiserte. Den flyktige friskheten trenger hjelp.

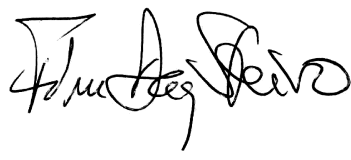

